\title{
DIAGNOSTICS AND THERAPY OF LEFT VENTRICULAR HYPERTROPHY IN HAEMODIALYSIS PATIENTS
}

Dejan Petrovic ${ }^{1}$, Nikola Jagic ${ }^{2}$, Vladimir Miloradovic ${ }^{3}$, Aleksandra Nikolic $^{3}$, Biljana Stojimirovic ${ }^{4}$

${ }^{1}$ Clinic for Urology and Nephrology, Center for Nephrology and Dialysis, Clinical Center "Kragujevac", Kragujevac ${ }^{2}$ Center for Radiology Diagnostics, Department for Interventional Radiology, Clinical Center “Kragujevac”,Kragujevac ${ }^{3}$ Clinic for Internal Medicine, Clinical Center "Kragujevac", Kragujevac

${ }^{4}$ Institut for Urology and Nephrology, Clinic for Nephrology, Clinical Center of Serbia, Belgrade, Serbia

\section{DIJAGNOSTIKA I LEČENJE HIPERTROFIJE LEVE IOMORE KOD BOLESNIKA NA HEMODIJALIZI \\ Dejan Petrović ${ }^{1}$, Nikola Jagić ${ }^{2}$, Vladimir Miloradović ${ }^{3}$, Aleksandra Nikolić ${ }^{3}$, Biljana Stojimirović $^{4}$ \\ ${ }^{1}$ Klinika za urologiju i nefrologiju, Centar za nefrologiju i dijalizu, KC Kragujevac, Kragujevac \\ ${ }^{2}$ Centar za radiologiju, Odsek interventne radiologije, KC “Kragujevac”, Kragujevac \\ ${ }^{3}$ Klinika za internu medicinu, KC “Kragujevac”, Kragujevac \\ ${ }^{4}$ Institut za urologiju i nefrologiju, Klinika za nefrologiju, KC Srbije, Beograd, Srbija}

Received / Primljen: 10. 01. 2011.

Accepted / Prihvaćen: 03. 04. 2011.

\section{ABSTRACT}

Cardiovascular diseases present a leading cause of death in patients treated with haemodialysis. The rate of cardiovascular mortality in this population is approximately $9 \%$ on an annual basis, with left ventricular hypertrophy, ischemic heart diseases and heart failure having the highest rates of mortality. Left ventricular hypertrophy is present in 75-80\% of haemodialysis-treated patients. The most important risk factors for the progression of left ventricular hypertrophy are: hypertension, arteriosclerosis, secondary aortic stenosis, anaemia, increased volume of extracellular fluid and increased blood flow through the vascular access for haemodialysis. Left ventricular hypertrophy is present when the left ventricular mass index on echocardiography exceeds $131 \mathrm{~g} / \mathrm{m}^{2}$ in males and $100 \mathrm{~g} / \mathrm{m}^{2}$ in females. Left ventricular hypertrophy is a risk factor of unfavourable outcome in patients treated with haemodialysis. The identification of patients with increased risk of progression of left ventricular hypertrophy, the timely implementation of adequate treatment, and the realisation and maintenance of targeted values of risk factors decelerates the progression of the hypertrophy and leads to the regression of existing left ventricular hypertrophy, the reduction of cardiovascular morbidity and mortality rates and the improvement of the quality of life of patients treated with haemodialysis.

Key words: risk factors, left ventricular hypertrophy, echocardiography, haemodialysis

\section{SAŽETAK}

Kardiovaskularne bolesti su vodeći uzrok smrti bolesnika koji se leče hemodijalizom. Stopa kardiovaskularnog mortaliteta kod ovih bolesnika iznosi približno 9\% godišnje, a među kardiovaskularnim bolestima najveća je prevalencija hipertrofije leve komore, ishemijske bolesti srca $i$ srčane slabosti. Hipertrofiju leve komore ima 75$80 \%$ bolesnika koji se leče hemodijalizom. Najznačajniji faktori rizika za razvoj hipertrofije leve komore su: hipertenzija, arterioskleroza, sekundarna aortna stenoza, anemija, povećan volumen ekstracelularne tečnosti i povećan protok krvi kroz vaskularni pristup za hemodijalizu. Hipertrofija leve komore je prisutna ako je na ehokardiografskom pregledu indeks mase leve komore veći od $131 \mathrm{~g} / \mathrm{m} 2$ kod muškaraca i veći od $100 \mathrm{~g} / \mathrm{m} 2 \mathrm{kod} z ̌ e n a$. Hipertrofija leve komore je faktor rizika za nepovoljan ishod bolesnika koji se leče hemodijalizom. Izdvajanje bolesnika koji imaju povećan rizik za razvoj hipertrofije leve komore, pravovremena primena odgovarajućeg lečenja, ostvarivanje $i$ održavanje ciljnih vrednosti faktora rizika usporavaju razvoj $i$ dovode do regresije postojeće hipertrofije leve komore, do smanjenja stope kardiovaskularnog morbiditeta i mortaliteta, i poboljšanja kvaliteta života bolesnika koji se leče hemodijalizom.

Ključne reči: faktori rizika, hipertrofija leve komore, ehokardiografija, hemodijaliza
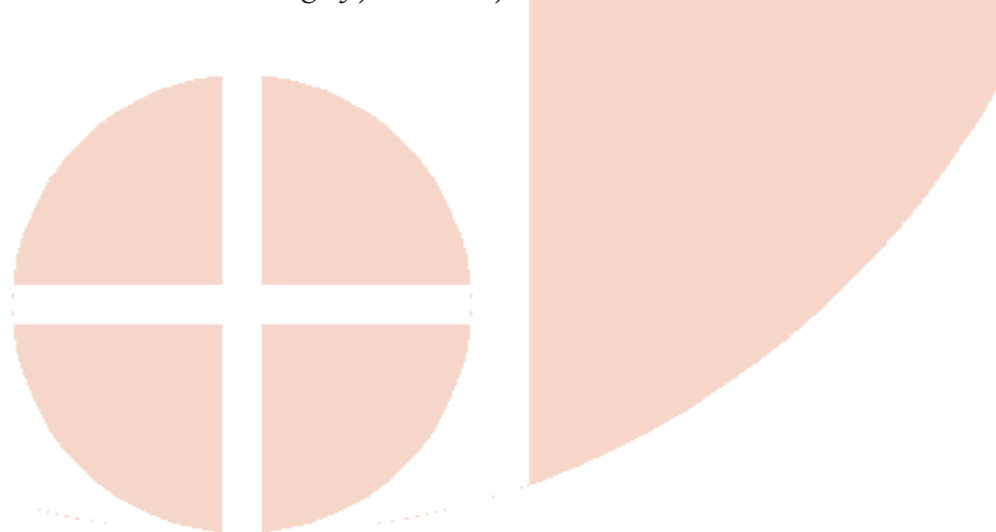

UDK 616.61-78-06 ; 616.1 / Ser J Exp Clin Res 2011; 12 (1): 37-40 


\section{INTRODUCTION}

Cardiovascular diseases present a leading cause of death in patients treated with haemodialysis $[1,2]$. The rate of cardiovascular mortality in this population is approximately $9 \%$ on an annual basis, with left ventricular hypertrophy, ischemic heart diseases and heart failure having the highest rates of mortality $[1,2]$.

\section{METHODS}

For this study, the Medline database was used. The following key words were used for searching: risk factors, left ventricular hypertrophy, echocardiography, and haemodialysis. About 40.000 references were found dealing with these types of problems. Systematic review articles and well-controlled clinical studies were singled out. Editor's letters and uncontrolled clinical studies were not used. Systematic review articles were used and analysed by the National Kidney Foundation Kidney Disease Outcome Quality Initiative (NKF KDOQI), which confirmed the validity and quality of the selected references.

\section{RE SULTS}

\section{Aetiopathogenesis of left ventricle hypertrophy}

The most important risk factors of left ventricle hypertrophy in haemodialysis patients are hypertension, arteriosclerosis, adult aortic stenosis, anaemia, increased blood flow through the vascular access for haemodialysis and increased volume of extracellular fluid [3, 4]. Pressure overloads of the left ventricle due to hypertension, aortic stenosis and arteriosclerosis of blood vessels can cause thickening of the left ventricle wall without the enlargement of the ventricle diameter (concentric left ventricle hypertrophy) [5, 6]. Volume overloads of the left ventricle due to increased sodium and water intake, anaemia and increased blood flow through the vascular access for haemodialysis $\left(Q_{A V} \geq 1000 \mathrm{ml} / \mathrm{min}\right)$ cause the ventricle wall to become thickened and cause an enlargement of ventricle diameter (eccentric left ventricle hypertrophy) $[5,6]$. The development of left ventricle hypertrophy and fibrosis of the myocardial interstitium can also be affected by factors that do not depend on the afterload and preload, such as microinflammation, oxidative stress, the activation of the intracardial renin-angiotensin systemRAS, the vitamin D deficiency and uncontrolled secondary hyperparathyroidism, scheme 1 [7-10]. Left ventricle hypertrophy goes through two phases. Adaptive hypertrophy is actually the response to increased tension stress to the left ventricle wall and has a protective function. When volume and pressure overload the left ventricle to the point of cardiac muscle failure, adaptive hypertrophy becomes maladaptive left ventricle hypertrophy, with myocyte loss, heart failure and, eventually, death [11].

\section{Diagnostics of left ventricular hypertrophy}

Morphological and functional disorders of the left ventricle in haemodialysis patients include systolic disorder, concentric hypertrophy, eccentric hypertrophy, left ventricle dilation and diastolic dysfunction. The systolic function of the left ventricle is disturbed when echocardiography reveals that the fractional shortening of the left ventricle (FSLV) is $\leq 25 \%$ and that the ejection fraction of the left ventricle (EFLV) is $\leq 50 \%$ [12-14]. Concentric hypertrophy of the left ventricle is defined by a left ventricle mass index- $(\mathrm{LVMi})>131 \mathrm{~g} / \mathrm{m}^{2}$ in males and $>100$ $\mathrm{g} / \mathrm{m}^{2}$ in females and a relative wall thickness of the left ventricle $($ RWT $)>45 \%$ [12-14]. Eccentric hypertrophy of the left ventricle is characterised by an increased left ventricle mass index (LVMi $>131 \mathrm{~g} / \mathrm{m}^{2}$ in males and $>100 \mathrm{~g} /$ $\mathrm{m}^{2}$ in females) and an RWT $\leq 45 \%$ [12-14]. An echochardiographic estimation of the left ventricle function in diastole is based upon the measurement of the velocity of early (E) and late (A) components of blood flow through the mitral valve and their relative ratio E/A. There are three types of left ventricle diastolic dysfunction: relaxation disorder $[\mathrm{VmaxE} / \mathrm{Vmax} \mathrm{A}<1,0$; $\mathrm{E}$ wave deceleration time $\left(\mathrm{DT}_{\mathrm{E}}\right)>250 \mathrm{~ms}$; and isovolumetric relaxation of the left ventricle $($ IVRT) $>100 \mathrm{~ms}$; ; pseudonormalisation and restriction disturbance $\left[\mathrm{VmaxE} / \mathrm{VmaxA}>1,6 ; \mathrm{DT}_{\mathrm{E}}<150\right.$ $\mathrm{ms}$; and IVRT < $60 \mathrm{~ms}$ ] [15]. Cardiac Magnetic Resonance Imaging (CMRI) is the golden standard for remodelling of the left ventricle and for the estimation of myocardial interstitium fibrosis in haemodialysis patients [16].

\section{Clinical importance of left ventricular hypertrophy}

Left ventricle hypertrophy is accompanied by disordered diastolic function (50-60\% of haemodialysis patients), by ventricle arrhythmias (dispersion interval (QTd) $>50 \mathrm{~ms}$ ), by de novo ischemic heart disease (in patients with LVMi > $\left.160 \mathrm{~g} / \mathrm{m}^{2}\right)$ and by unfavourable outcomes in haemodialysis patients [17-19]. A high left ventricle mass index (LVMi > $120 \mathrm{~g} / \mathrm{m}^{2}$ ) and an LV mass/volume ratio (LVMi/iEDV) $>2,2$ $\mathrm{g} / \mathrm{ml}$ are predictors of a poor outcome in dialysis patients with a normal $\mathrm{LV}$ volume (iEDV $\leq 90 \mathrm{ml} / \mathrm{m}^{2}$ ) and a normal systolic function (FS > 25\%, EF > 50\%) [20, 21].

\section{Therapy of left ventricular hypertrophy}

Well-timed risk factor detection and adequate therapy help regression of left ventricle hypertrophy in haemodialysis patients [22-25]. Results of large, well-controlled clinical trials stress that the management of anaemia and blood pressure control, the correction of metabolic disorders of calcium, phosphate, vitamin D and parathormone (parathyroid hormone), as well as the individualisation of treatment of haemodialysis as the most important factors in the successful management of left ventricle hypertrophy [22-25].

Anaemia is an important cause of left ventricle hypertrophy, and a decrease in haemoglobin of $10 \mathrm{~g} / \mathrm{l}$ is 


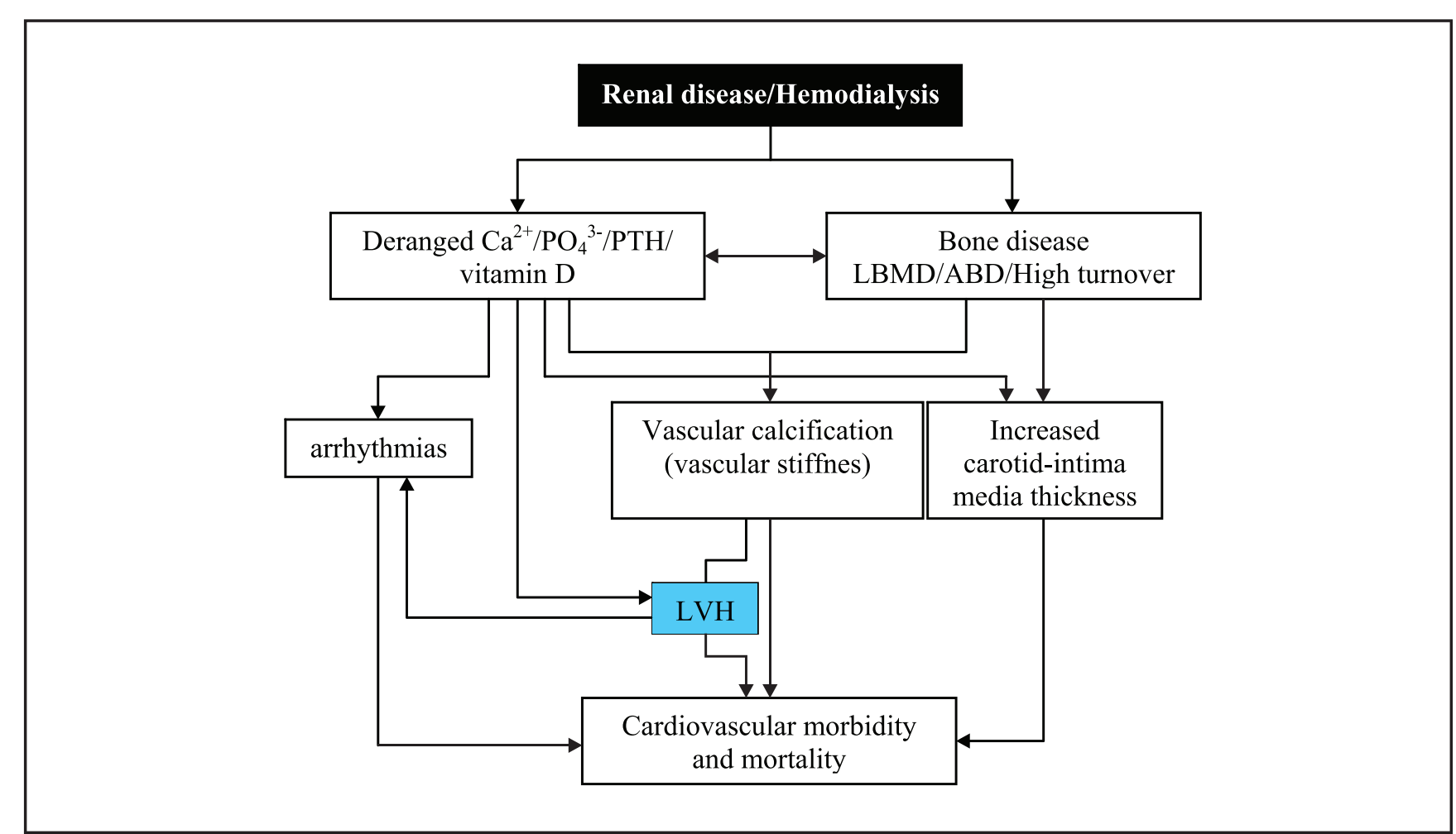

Shema 1. Impact of calcium and phosphate metabolism dosorder on progression of

cardiovascular morbidity and mortality in hemodialysis patients

associated with an increase in the LVMi of $10 \mathrm{~g} / \mathrm{m}^{2}[25$, 26]. Erythropoietin treatment and iron supplementation should maintain the haemoglobin levels at 110 $120 \mathrm{~g} / \mathrm{l}(\mathrm{Hct}=33-36 \%)$ and feritin levels at 200-500 $\mathrm{ng} / \mathrm{ml}[25,26]$. Hypertension is an important risk factor for the development of left ventricle hypertrophy, and an increase in the mean arterial blood pressure of $10 \mathrm{mmHg}$ increases the left ventricle mass index by 7,2 $\mathrm{g} / \mathrm{m}^{2}$ [27]. In haemodialysis patients, before haemodialysis, the arterial blood pressure should be $\leq 140 / 90$ $\mathrm{mmHg}$ and should be $\leq 130 / 80 \mathrm{mmHg}$ afterwards. Angiotensin I convertase blockers, angiotensin II receptor blockers and $ß$-blockers should be used in the treatment of hypertension [27].

Arteriosclerosis increases peripheral vascular resistance, overloads the left ventricle because of increased blood pressure and acts as a stimulus for left ventricle remodelling [28]. The most important risk factors for the development of arteriosclerosis (media calcification) and for heart valve calcification in haemodialysis patients are hyperphosphatemia, increased solubility products and secondary hyperparathyroidism [29-31]. Calcification of the arterial medial wall, increased artery stiffness, heart valve calcification and decreased opening of the aortic valve leaflets leads to the development of left ventricle concentric hypertrophy, and an increased serum parathormone level also leads to a significant myocardial interstitial fibrosis (fibroblast proliferation, increased creation and deposition of extracellular ma- trix proteins in the myocardial interstitium) in haemodialysis patients [29-31]. Hygienic and diet regimens, phosphate binders, active vitamin D3 metabolites, and calcimimetics should maintain the phosphate concentration at $<1,6 \mathrm{mmol} / \mathrm{l}$, the solubility product $\left(\left[\mathrm{Ca}^{2+}\right]\right.$ $\left.x\left[\mathrm{PO}_{4}^{3-}\right]\right)$ at $\leq 4,4 \mathrm{mmol}^{2} / \mathrm{l}^{2}$, the concentration of $25(\mathrm{OH})$ $\mathrm{D}_{3}$ at $>30 \mathrm{ng} / \mathrm{ml}$ and the concentration of iPTH od at $100-300 \mathrm{pg} / \mathrm{ml}(\mathrm{iPTH}<500 \mathrm{pg} / \mathrm{ml})$ [29-34].

Haemodialysis treatment significantly reduces left ventricle hypertrophy. Every-day short-term haemodialysis (6 times weekly, 3h) for 12 months decreases left ventricle hypertrophy by $30 \%$, as compared to conventional haemodialysis (3 times weekly, 4h) [24]. Clinical trial results show that night-time haemodialysis (3 times weekly, 6-8h) during the six-month period significantly reduces left ventricle hypertrophy compared to conventional haemodialysis (3 times weekly, 4h) [25].

Recognising patients with an increased risk for the development of left ventricular hypertrophy and implementing adequate treatment to achieve target values of risk factors decreases cardiovascular morbidity and mortality and improves the quality of life in patients receiving regular haemodialysis treatments.

Acknowledgments: The authors would like to express their gratitude for Grant N0175014 of the Ministry of Science and Technological Development of The Republic of Serbia, which partially financed this study. 


\section{REFERENCES}

1. Parfrey PS. Cardiac disease in dialysis patients: diagnosis, burden of disease, prognosis, risk factors and management. Nephrol Dial Transplant 2000; 15(Suppl 5): 5868.

2. Petrović D, Stojimirović B. Cardiovascular morbidity and mortality in hemodialysis patients - epidemiological analysis. Vojnosanit Pregl 2008; 65(12): 893-900.

3. Zoccali C, Mallamaci F, Tripepi G. Novel Cardiovascular Risk Factors in End-Stage Renal Disease. J Am Soc Nephrol 2004; 15(Suppl 1): 77-80.

4. Petrović D, Jagić N, Miloradović V, Stojimirović B. Non-tradicional risk factors for development of cardiovascular complications in haemodialysis patients. Ser J Exp Clin Res 2009; 10(3): 95-102.

5. London GM. Left ventricular alterations and endstage renal disease. Nephrol Dial Transplant 2002; 17(Suppl 1): 29-36.

6. London GM. Cardiovascular Disease in Chronic Renal Failure: Patophysiologic Aspects. Semin Dial 2003; 16(2): 85-94.

7. Raggi P, Kleerekoper M. Contribution of Bone and Mineral Abnormalities to Cardiovascular Disease in Patients with Chronic Kidney Disease. Clin J Am Soc Nephrol 2008; 3(3): 836-43.

8. Valdivieslo JM, Ayus JC. Role of vitamin D receptor activators on cardiovascular risk. Kidney Int 2008; 74(Suppl 111): 44-9.

9. Eddington $\mathrm{H}$, Klara PA. The association of chronic kidney disease - mineral bone disorder and cardiovascular risk. J Ren Car 2010; 36(Suppl 1): 61-7.

10. Cozzolino M, Ketteler M, Zehnder D. The vitamin D system: a crosstalk between the heart and kidney. Eur J Heart Fail 2010; 12(10): 1031-41.

11. Rigatto C, Parfrey PS. Uraemic Cardiomyopathy: an Overload Cardiomyopathy. J Clin Basic Cardiol 2001; 4(2): 93-5.

12. Parfrey PS, Collingwood P, Foley RN, Bahrle A. Left ventricular disorders detected by $\mathrm{M}$-meode echocardiography in chronic uraemia. Nephrol Dial Transplant 1996; 11(7): 1328-31.

13. Middleton RJ, Parfrey PS, Foley RN. Left Ventricular Hypertrophy in the Renal Patient. J Am Soc Nephrol 2001; 12(5): 1079-84.

14. McIntyre C.W., John S.G., Jefferies H.J. Advances in the cardiovascular assessment of patients with chronic kidney disease. NDT Plus, 2008; 1(6): 383-91.

15. Cohen-Solal A. Left ventricular diastolic dysfunction: pathophysiology, diagnosis and treatment. Nephrol Dial Transplant 1998; 13(Suppl 4): 3-5.

16. Sood MM, Pauly RP, Rigatto C, Komenda P. Left ventricular dysfunction in the haemodialysis population. NDT Plus 2008; 1(4): 199-205.

17. Johnston N, Dargie H, Jardine A. Diagnosis and treatment of coronary artery disease in patients with chronic kidney disease. Heart 2008; 94(8): 1080-8.
18. Petrović D, Miloradović V, Poskurica M, Stojimirović B. Diagnostics and treatment of ischemic heart disease in hemodialysis patients. Vojnosanit Pregl 2009; 66(11): 897-903.

19. Voroneanu L, Covic A. Arrythmias in hemodialysis patients. J Nephrol 2009; 22(6): 716-25.

20. Foley RN, Parfrey PS, Harnett JD, Kent GM, Murray DC, Barre PE. The prognostic importance of left ventricular geometry in uremic cardiomyopathy. J Am Soc Nephrol 1995; 5(12): 2024-31.

21. Petrović D, Jagić N, Miloradović V, Stojimirović B. Left ventricular hypertrophy - risk factor for poor outcome in hemodialysis patients. Ser J Exp Clin Res 2008; 9(4): 129-35.

22. De Bie MK, van Dam B, Gaasbeek A, van Buren M, van Erven L, Bax JJ, et al. The current status of interventions aiming at reducing sudden cardiac death in dialysis patients. Eur Heart J 2009; 30(13): 1559-64.

23. Henrich WL. Optimal Cardiovascular Therapy for Patients with ESRD over the Next Several Years. Clin J Am Soc Nephrol 2009; 4(Suppl 1): 106-9.

24. Hampl H, Riedel E. Cardiac Disease in the Dialysis Patient: Good, Better, Best Clinical Practice. Blood Purif 2009; 27(1): 99-113.

25. Glassock RJ, Pecoits-Filho R, Barberato SH. Left Ventricular Mass in Chronic Kidney Disease and ERSD. Clin J Am Soc Nephrol 2009; 4(Suppl 1): 79-91.

26. Stojimirović B, Petrović D, Obrenović R. Left ventricular hypertrophy in patients on hemodialysis: importance of anaemia. Med Rev 2007; LX (Suppl 2): 155-9.

27. Lynn KL. Hypertension and Survival in Hemodialysis Patients. Semin Dial 2004; 17(4): 270-4.

28. London GM. Arterial function in renal failure. Nephrol Dial Transplant 1998; 13(Suppl 4): 125.

29. Petrović D, Stojimirović B. Secondary hiperparathyroidism - risk factor for development of cardiovascular complications in hemodialysis patients. Med Rev 2010; LXIII(9-10): (in press).

30. Petrović D, Obrenović R, Stojimirović B. Risk Factors for Aortic Valve Calcification in Patients on Regular Hemodialysis. Int J Artif Organs 2009; 32(3): 173-9.

31. Hörl WH. The clinical consequences of secondary hyperparathyroidism: focus on clinical outcomes. Nephrol Dial Transplant 2004; 19(Suppl 5): 2-8.

32. Messa P, Macario F, Yaqoob M, Bouman K, Braun J, von Albertini B, et al. The OPTIMA Study: Assessing a New Cinacalcet (Sensipar/Mimpara) Treatment Algorithm for Secondary Hyperparathyroidism. Clin J Am Soc Nephrol 2008; 3(1): 36-45.

33. Valdivieslo JM, Ayus JC. Role of vitamin D receptor activators on cardiovascular risk. Kidney Int 2008; 74(Suppl 111): 44-9.

34. Artaza JN, Mehrotra R, Norris KC. Vitamin D and the Cardiovascular System. Clin J Am Soc Nephrol 2009; 4(9): 1515-22. 